\title{
Effect of Curing Water Availability and Composition on Cement Hydration
}

\author{
by Md Sarwar Siddiqui, Wesley Nyberg, Wilson Smith, Brett Blackwell, and Kyle A. Riding
}

\begin{abstract}
Curing can help concrete reach its full strength and durability potential. The effect of sealing the concrete with plastic or formwork, use of a liquid curing compound, wet curing, and internal curing with saturated lightweight aggregates on the cement degree of hydration $(\mathrm{DOH})$ development with time was examined using isothermal calorimetry. Curing water amount, curing water ionic concentration, and sample thickness were varied. Finally, curing application timing was studied by comparing strength development of concrete cylinders sealed, placed in a moist room after 24 hours sealed, and immersed in a water bath immediately after finishing. Increasing the height of curing water decreased the height of heat of hydration rate peaks. Curing water ionic concentration affected the setting time and heat of hydration rate peak heights. Strength results show delayed curing can result in significant strength loss because of the difficulty for water to penetrate the already-hardened concrete.
\end{abstract}

Keywords: curing; early hydration; internal curing; ionic concentration; pore solution.

\section{INTRODUCTION}

Concrete curing can improve strength, durability, dimensional stability, freezing-and-thawing resistance, resistance to surface wear, and reduces permeability and ion penetration. For Type I cement, curing can increase the strength by more than $58 \%$ after 6 months (Price 1951). To achieve complete cement hydration, a water-cementitious material ratio $(w / c m)$ greater than 0.42 is theoretically needed (Powers and Brownyard 1948; Jensen et al. 1999). In practice, however, complete hydration is rare. Studies have shown that once the relative humidity within the capillary drops below 80\%, hydration virtually stops (Powers 1947). To keep the concrete pore relative humidity high and continue hydration, an additional supply of water is needed.

Curing is even more critical for concrete with low $w / \mathrm{cm}$ for significant improvement of cement hydration. Heterogeneous microstructures develop in sealed low $w / \mathrm{cm}$ cement pastes, with zones of high and low density not normally seen in samples that are water-cured (Jaouadi 2008). Zones of low density can create zones of weakness to lower strength. Lower $w / \mathrm{cm}$ also results in a less continuous pore network and a more rapid decrease of pore relative humidity under sealed conditions. The use of low $w / \mathrm{cm}$ also contributes to the development of autogenous shrinkage of concrete (Jensen and Hansen 1996). Autogenous shrinkage occurs because of a vapor-water interface that develops when water is used up. This forms a surface tension and capillary under-pressure that creates tensile stresses on pore walls (Grasley 2006).

Conventional curing techniques, such as water ponding, water spraying, fogging, plastic film, wet burlap, and liquid membranes improve curing by reducing moisture loss and providing an additional supply of water to the near-surface layers. This method generally depends on one-dimensional movement of water and has a very limited depth of influence. Internal curing has been developed to help water reach cement grains on the concrete interior where ponded water has not been able to reach (Bentz et al. 2005; Klieger 1957; Mather 2001; Weber and Reinhardt 1997). Internal curing systems store water inside the concrete in highly absorbent material, such as saturated fine lightweight aggregate as internal reservoirs (FLAIR) (Weber and Reinhardt 1997; Hoff and Elimov 1995; Kovler and Jensen 2005; Kovler et al. 2004; Villarreal 2005) or super-absorbent polymers (Kovler and Jensen 2005; Jensen and Hansen 2001; Jensen and Hansen 2002). Water is kept inside the internal reservoirs during mixing, which later slowly releases into the cement matrix. The concrete diffusivity decreases as the hydration increases. The curing water influence zone correspondingly decreases with time from $20 \mathrm{~mm}$ (0.79 in.) at 1 day to $0.25 \mathrm{~mm}$ (0.01 in.) at 28 days (Bentz et al. 2007).

The effectiveness of concrete curing will be dependent on when the curing is applied. It was found with thin (2 to $5 \mathrm{~mm}$ [0.079 to $0.197 \mathrm{in.]}$ ) cement paste samples that the degree of hydration (DOH) at 92 days was similar for samples with water curing started at 4 hours and 7 days (Bentz and Stutzman 2006). Recently, some contractors and material suppliers have advocated for beginning curing of concrete cylinders immediately after finishing for high-performance concrete. The influence of the timing of curing water application on strength is important because after setting it might be more difficult for water to penetrate the concrete in larger samples and aid in curing. Supplying water to the concrete during the initial curing period could increase the $\mathrm{DOH}$ throughout the concrete cylinder and increase strength in the bulk. The water, however, could also increase the effective $w / \mathrm{cm}$ at the top surface. A weak plane at the top could cause lower compressive strength tests.

Isothermal calorimetry was recently used by Lura et al. (2010) to study the difference in hydration development as measured using chemical shrinkage and isothermal calorimetry with and without water curing. It was found that the water curing altered the aluminate reactions during the first day and increased the overall hydration after 24 hours. Only one specimen height and water amount was used, as the purpose was to compare the effects of the curing used in the two measurement methods.

ACI Materials Journal, V. 110, No. 3, May-June 2013.

MS No. M-2011-315.R1 received March 5, 2012, and reviewed under Institute publication policies. Copyright (C) 2013, American Concrete Institute. All rights reserved, including the making of copies unless permission is obtained from the copyright proprietors. Pertinent discussion including author's closure, if any, will be published in the March-April 2014 ACI Materials Journal if the discussion is received by December 1,2013 . 
$\overline{\text { ACI member Md Sarwar Siddiqui is a PhD Candidate at the University of Texas at }}$ Austin, Austin, TX. He received his MS from Kansas State University, Manhattan, KS, in 2010. He is a member of ACI Committee 221, Aggregates. His research interests include early-age properties of concrete, influence of aggregate on concrete properties, sustainable construction materials, and pavement concrete.

Wesley Nyberg received his BS and MS from Kansas State University in 2010 and 2012 , respectively.

Wilson Smith is a Staff Engineer with Kleinfelder. He received his BS and MS from Kansas State University in 2009 and 2012, respectively.

Brett Blackwell is an Assistant Structural Engineer at Burns \& McDonnell. He received his BS from Kansas State University in 2010.

ACI member Kyle A. Riding is an Assistant Professor in the Department of Civil Engineering at Kansas State University. He received his MSE and PhD from the University of Texas at Austin in 2004 and 2007, respectively. He is Secretary of ACI Committee 231, Properties of Concrete at Early Ages, and a member of ACI Committee 236, Material Science of Concrete. He received the Wason Medal for Materials Research in 2011.

Table 1-Physical and chemical properties of cementitious materials: percentages given are by mass

\begin{tabular}{|c|c|c|c|}
\hline Properties & Type I cement & Slag & Silica fume \\
\hline Specific gravity & - & 2.5 & - \\
\hline $\mathrm{SiO}_{2}, \%$ & 21.34 & 33.83 & 90.4 \\
\hline $\mathrm{Al}_{2} \mathrm{O}_{3}, \%$ & 4.74 & 11.45 & 0.14 \\
\hline $\mathrm{Fe}_{2} \mathrm{O}_{3}, \%$ & 3.29 & 0.49 & 0.87 \\
\hline $\mathrm{Si}+\mathrm{Al}+\mathrm{Fe}, \%$ & 29.37 & 45.77 & 91.41 \\
\hline $\mathrm{CaO}, \%$ & 62.94 & 38.52 & 0.64 \\
\hline $\mathrm{MgO}, \%$ & 1.69 & 11.63 & 2.53 \\
\hline $\mathrm{SO}_{3}, \%$ & 2.68 & 2.55 & 0 \\
\hline $\mathrm{Na}_{2} \mathrm{O}, \%$ & 0.14 & 0.28 & 0.15 \\
\hline $\mathrm{K}_{2} \mathrm{O}, \%$ & 0.53 & 0.38 & 0.82 \\
\hline Total alkalis as $\mathrm{Na}_{2} \mathrm{O}$ & 0.49 & 0.53 & 0.69 \\
\hline Blaine fineness, $\mathrm{m}^{2} / \mathrm{kg}$ & 360.1 & - & - \\
\hline $\mathrm{C}_{3} \mathrm{~S}, \%$ & 66.96 & - & - \\
\hline $\mathrm{C}_{2} \mathrm{~S}, \%$ & 16.49 & - & - \\
\hline $\mathrm{C}_{3} \mathrm{~A}, \%$ & 2.92 & - & - \\
\hline $\mathrm{C}_{4} \mathrm{AF}, \%$ & 9.29 & - & - \\
\hline Gypsum, \% & 2.31 & - & - \\
\hline Hemihydrate, $\%$ & 1.68 & - & - \\
\hline Arcanite, $\%$ & 0.23 & - & - \\
\hline
\end{tabular}

Table 2-Concrete mixture proportions

\begin{tabular}{c|c|c|c|c|c}
\hline \multirow{4}{*}{ Content } & $\begin{array}{c}\text { Water, } \\
\mathrm{kg} / \mathrm{m}^{3} \\
\left(\mathrm{lb} / \mathrm{yd}^{3}\right)\end{array}$ & $\begin{array}{c}\text { Cement, } \\
\mathrm{kg} / \mathrm{m}^{3} \\
\left(\mathrm{lb} / \mathrm{yd}^{3}\right)\end{array}$ & $\begin{array}{c}\text { Coarse } \\
\text { aggregate, } \\
\mathrm{kg} / \mathrm{m}^{3} \\
\left(\mathrm{lb} / \mathrm{yd}^{3}\right)\end{array}$ & $\begin{array}{c}\text { Fine } \\
\text { aggregate, } \\
\mathrm{kg} / \mathrm{m}^{3} \\
\left(\mathrm{lb} / \mathrm{yd}^{3}\right)\end{array}$ & $\begin{array}{c}\text { WRA, } \\
\mathrm{mL} / 100 \mathrm{~kg} \\
(\mathrm{oz} / \mathrm{cwt})\end{array}$ \\
\cline { 2 - 6 } & $\begin{array}{c}181 \\
(305)\end{array}$ & $\begin{array}{c}594 \\
(1001)\end{array}$ & $\begin{array}{c}1214 \\
(2046)\end{array}$ & $\begin{array}{c}374 \\
(631)\end{array}$ & $\begin{array}{c}36.3 \\
(5)\end{array}$ \\
\hline
\end{tabular}

This study was conducted to evaluate the ability of water curing, curing compounds, and FLAIR to increase the cement DOH. FLAIR is fine lightweight aggregate with internal porosity, which can store water for later release when the internal relative humidity of concrete drops. The effect of curing water amount on the cement DOH development was studied. Distilled water, lime-saturated water, and cement pore water (CPW) was also used to investigate the effects of ionic concentrations of curing water on hydration. Finally, the strength development was measured on cylinders made from a $0.32 \mathrm{w} / \mathrm{cm}$ concrete mixture under different curing methods. The cylinders were cured by immersion in water immediately after finishing, sealed for 24 hours followed by curing in a $100 \%$ relative humidity room, or sealed.

\section{RESEARCH SIGNIFICANCE}

Cement hydration test methods require different types of curing, giving potentially different results. This study examined the effects of curing methods commonly used in practice and in hydration experiments using the same hydration measurement technique: isothermal calorimetry. Additionally, changes in concrete cylinder curing procedures for high-strength concrete have been recently considered to allow for access to water. This study examined the effects of curing application time on low $w / \mathrm{cm}$ concrete strength development.

\section{MATERIALS}

An ASTM C150/C150M (2002) Type I cement, ASTM C1240 (2011) silica fume, and ASTM C989/C989M (2005) slag cement were used in this study. The physical and chemical properties of cementitious materials that were used in this study are presented in Table 1. A mid-range water-reducing admixture (WRA) used at $87 \mathrm{~mL} / 100 \mathrm{~kg}$ (12 oz/cwt) was used in mortar mixtures for both siliceous and lightweight fine aggregate to improve workability. An ASTM C33/C33M (2011) siliceous fine aggregate and a lightweight fine aggregate were used in the mortar mixtures. The bulk specific gravity (SG) and percent absorption of siliceous fine aggregate used in the calorimetry experiments were 2.5 and $0.42 \%$, respectively. Lightweight fine aggregates were sieved and recombined in the laboratory to have the same gradation as the siliceous fine aggregate. The lightweight fine aggregate bulk SG and absorption after 48 hours of soaking were 1.49 and $16.87 \%$, respectively. The bulk SG and absorption capacity of the coarse and fine aggregate used for the concrete mixture were $2.58,2.38 \%$ and 2.58 , $0.54 \%$, respectively.

The $w / \mathrm{cm}$ of cement pastes was varied from 0.275 to 0.35 to study the interplay between curing method and $w / \mathrm{cm}$. The mortar fine aggregate-cementitious material ratio was 2.75 by weight for siliceous aggregate. Mortars with a $w / \mathrm{cm}$ of 0.45 were used to study the effects of FLAIR on cement hydration. Ten percent, 20\%, 30\%, 40\%, 50\%, and $100 \%$ of siliceous aggregate was replaced by volume with lightweight aggregate presoaked for 48 hours to determine the effectiveness of concrete internal curing with FLAIR. The concrete mixture was made using the mixture proportions shown in Table 2.

A water-based liquid curing compound was used in this study. Distilled water, saturated lime water, and CPW were used to investigate the effects of water curing and ionic concentration of curing water on hydration. Fresh CPW was collected by extracting water from cement paste made with the same cement used in this study and with a $w / \mathrm{cm}$ of 1.5 . The schematic diagram of the vacuum filtration setup used to extract the pore solution from the cement paste is shown in Fig. 1 . 


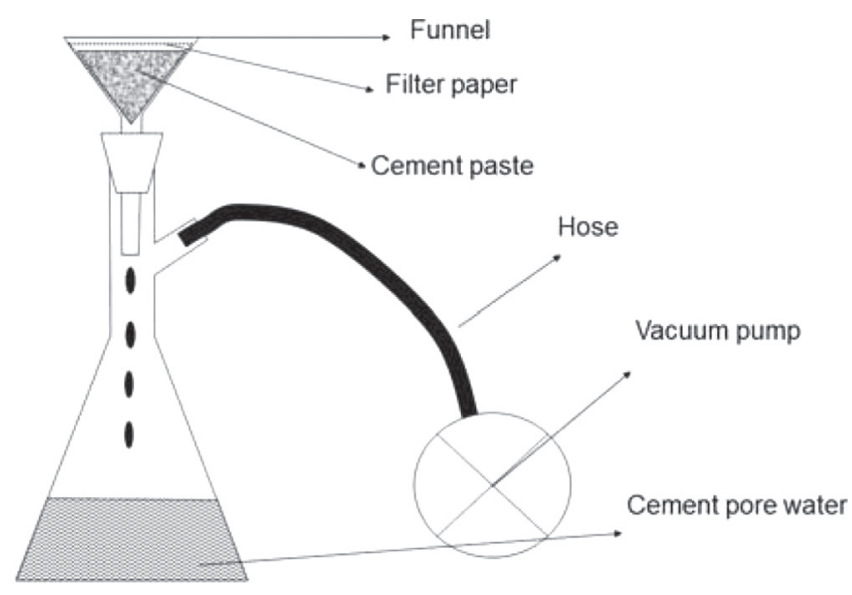

Fig. 1-Schematic diagram of cement paste pore water vacuum filtration system.

\section{EXPERIMENTAL METHODS}

In this study, the ASTM C305 (2011) mixing procedure was followed for both cement paste and mortar mixing. Both the cement paste and mortar were mixed at room temperature and placed in the isothermal calorimeter within 15 minutes from the addition of water to the cementitious materials. Concrete was mixed according to ASTM C192/C192M (2007).

Distilled water, lime-saturated water, CPW, and curing compound were used to cure the cement paste samples. These curing substances were applied at the top of the cement paste or mortar samples. These liquids were gently applied to the sample surface so that the curing liquid did not disturb the cement paste and affect the $w / \mathrm{cm}$. The samples were sealed in their containers after the curing liquid was placed on top of the sample. Two layers of curing compound were sprayed on the sample surface to ensure complete cover.

The concrete compressive strength was measured using a 100 × 200 mm (4 × 8 in.) cylinder following ASTM C39/ C39M (2011). Concrete samples were cured in three different ways: sealed by keeping the concrete inside the plastic molds with the plastic lids firmly attached, immersed in water at $23 \pm 2{ }^{\circ} \mathrm{C}\left(73 \pm 3.5^{\circ} \mathrm{F}\right)$ immediately after finishing without a lid, and keeping the concrete inside of the plastic molds with the plastic lids firmly attached for 24 hours followed by demolding and storage in a $100 \%$ relative humidity room at $23 \pm 2^{\circ} \mathrm{C}\left(73 \pm 3.5^{\circ} \mathrm{F}\right)$.

An eight-channel isothermal calorimeter was used in this study to measure the heat evolution of the cementitious systems studied (Broda et al. 2002; Wadsö 2010). The cement and mortar samples were mixed, weighed, curing added when needed, and placed in the isothermal calorimeter within 15 minutes after beginning mixing. The $\mathrm{DOH}$ was then calculated from the cumulative heat of hydration using Eq. (1) through (3) (D'Aloia and Chanvillard 2002; Kada-Benameur et al. 2000; Van Breugel 1998; Copeland et al. 1960; De Schutter and Taerwe 1996)

$$
\alpha(t)=\frac{H(t)}{H_{u}}
$$

where $\alpha(t)$ is the $\mathrm{DOH}$ at time $t ; H(t)$ is the cumulative heat of hydration from time 0 to time $t$; and $H_{u}$ is the total heat available for reaction. The variable $H_{u}$ is a function of the

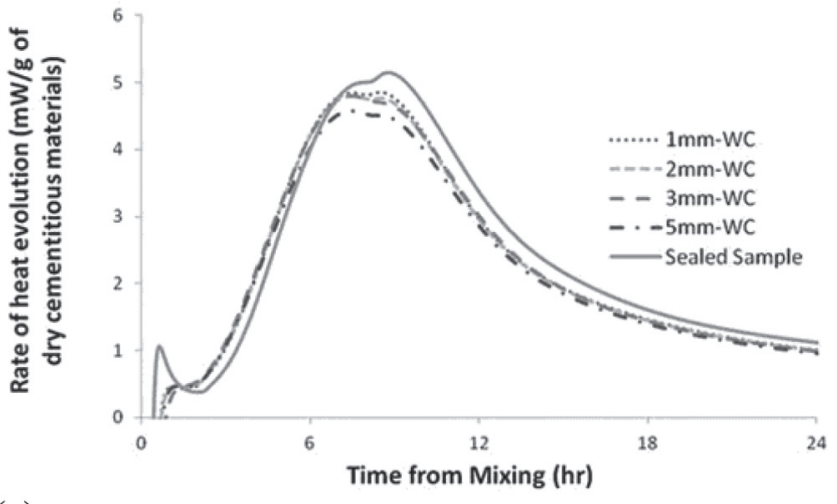

(a)

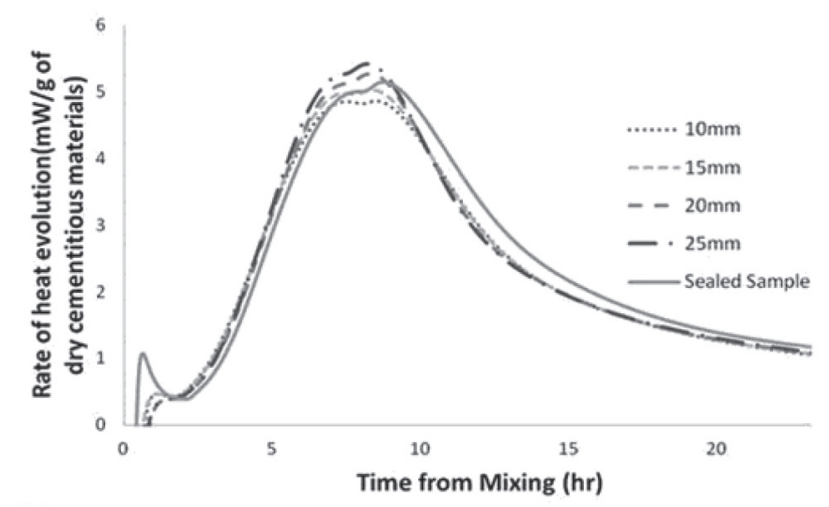

(b)

Fig. 2-Effect of curing water on rate of heat evolution for $100 \%$ Type I cement paste $(\mathrm{w} / \mathrm{cm}=0.35)$ at $23^{\circ} \mathrm{C}\left(73^{\circ} \mathrm{F}\right)$ : (a) effect of curing height for $10 \mathrm{~mm}$ (0.39 in.) thick sample; and $(b)$ effect of sample depth for $1 \mathrm{~mm}$ (0.03937 in.) curing water.

cement composition, amount, and type of supplementary cementitious materials (SCMs) and may be approximated as follows (Schindler and Folliard 2005)

$$
H_{u}=H_{c e m} \cdot P_{c e m}+461 \cdot P_{\text {slag }}+1800 \cdot P_{F A-C a O} \cdot P_{F A}
$$

where $P_{\text {slag }}$ is the slag to total cementitious content mass ratio; $P_{F A}$ is the fly ash to total cementitious content mass ratio; $P_{F A-C a O}$ is the fly ash $\mathrm{CaO}$ to total fly ash content mass ratio; $P_{c e m}$ is the portland cement to total cementitious content mass ratio; and $H_{c e m}$ is the available heat of hydration of the cement. The value $H_{c e m}$ can be approximated as shown in Eq. (3) (Schindler and Folliard 2005)

$$
\begin{gathered}
H_{c e m}=500 \cdot P_{C_{3} S}+260 \cdot P_{C_{2} S}+866 \cdot P_{C_{3} A}+ \\
420 \cdot P_{C_{4} A F}+624 \cdot P_{\mathrm{SO}_{3}}+1186 \cdot P_{\text {Free } \mathrm{Ca}}+850 \cdot P_{\mathrm{MgO}}
\end{gathered}
$$

where $H_{c e m}$ is the total heat of hydration of portland cement at $\alpha=1.0$; and $P_{i}$ is the ratio of the mass of the $i$-th component to total cement mass. Because the total heat available for reaction was calculated instead of measured, small errors in the DOH could result. Because comparisons for experiments with curing were made on the same cementitious materials, any small errors in the total heat available for reaction would not affect the overall curing method comparisons and conclusions. 


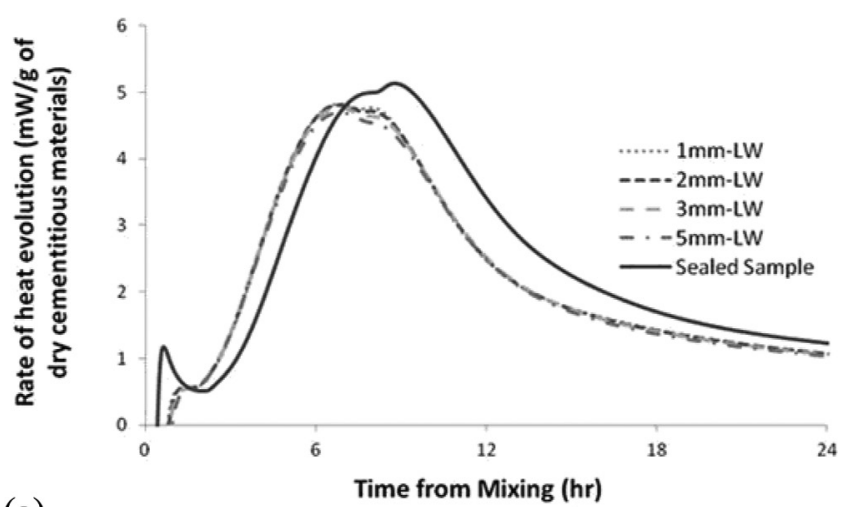

(a)

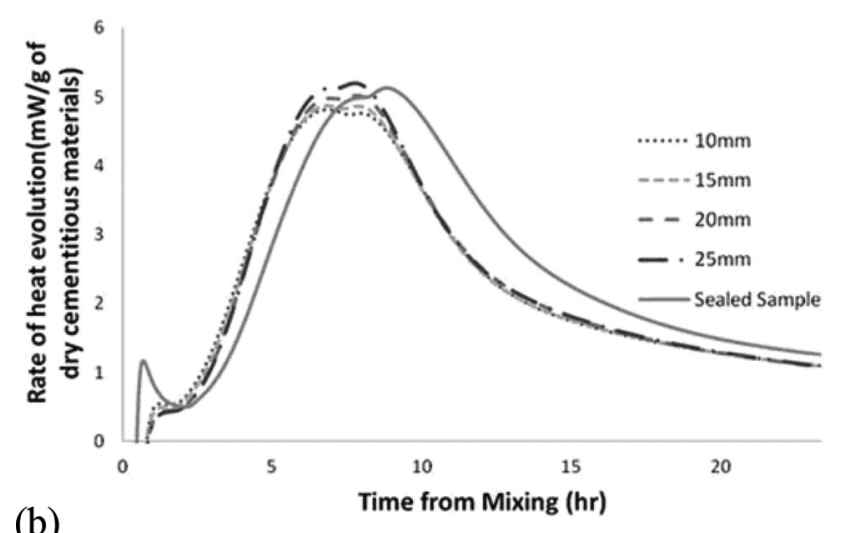

Fig. 3-Effect of lime-saturated water curing on rate of heat evolution for $100 \%$ Type I cement paste $(\mathrm{w} / \mathrm{cm}=0.35)$ at $23^{\circ} \mathrm{C}$ $\left(73^{\circ} \mathrm{F}\right)$ : (a) effect of curing height for $10 \mathrm{~mm}$ (0.39 in.) thick sample; and (b) effect of sample depth for $1 \mathrm{~mm}$ (0.03937 in.) lime-saturated water.

\section{RESULTS}

Figure 2 shows the effect of curing water thickness and sample thickness on the rate of heat evolution of the cement used in this study. As the curing water thickness increased, the maximum rate of heat evolution slightly decreased. The third hydration peak also decreased, confirming the decrease in aluminate hydration found by Lura et al. (2010). Increasing the ratio of the sample thickness to curing water thickness increased the maximum rate of heat evolution. This could be because the changes in ionic concentrations in the pore solution are lower for the larger amount of cement paste.

Figure 3 shows the effect of lime-saturated curing water height and sample thickness on the rate of heat evolution of cementitious materials. Lime-saturated water accelerated hydration, with the time of the second peak occurring over an hour before the sealed sample; however, sample thickness does not show any significant effect on the acceleration of the samples cured with lime-saturated water. The limesaturated water samples show a change in the ratio of the second and third peak heights, just as the samples cured with distilled water. Increasing sample height-to-curing water height ratio decreases this effect, most likely because of the lower pore water dilution from the decreased curing waterto-cement paste ratio. This trend is the same one as seen when curing with distilled water.
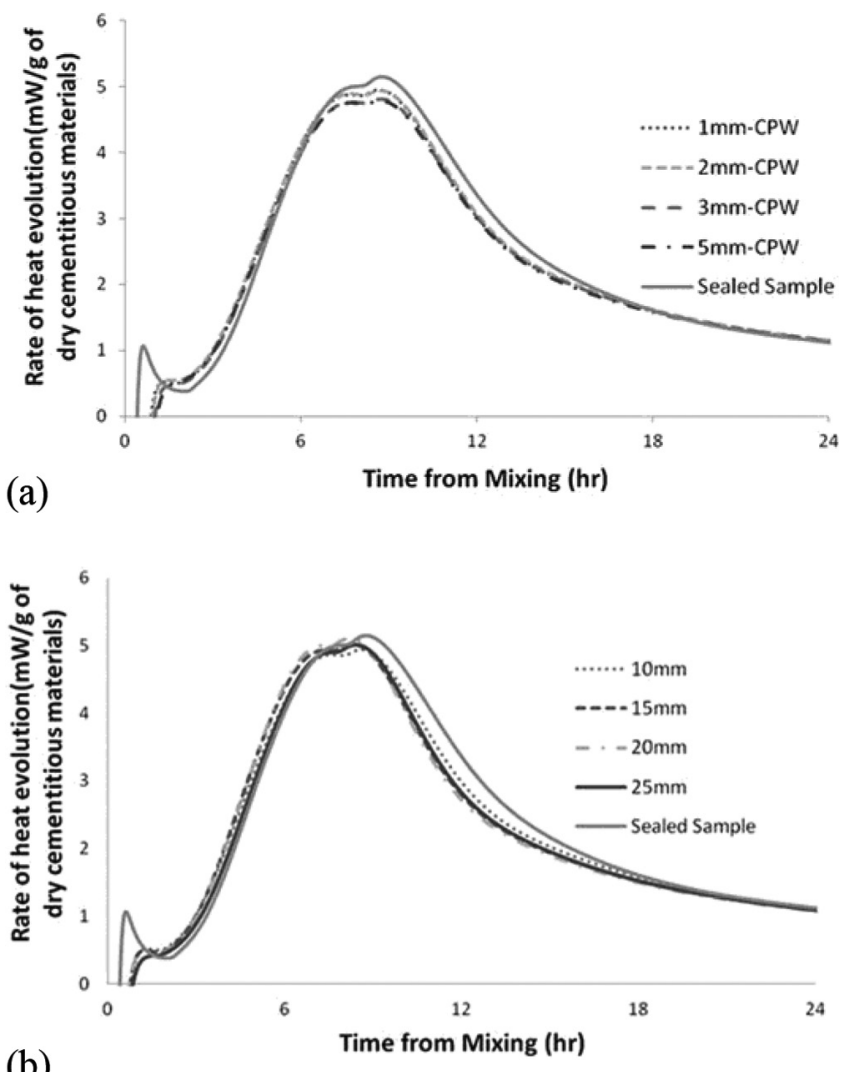

(b)

Fig. 4-Effect of cement paste pore water curing on rate of heat evolution for $100 \%$ Type I cement paste $(\mathrm{w} / \mathrm{cm}=0.35)$ at $23^{\circ} \mathrm{C}\left(73^{\circ} \mathrm{F}\right)$ : (a) effect of curing height for $10 \mathrm{~mm}$ (0.39 in.) thick sample; and (b) effect of sample depth for $1 \mathrm{~mm}$ (0.3937 in.) cement paste pore water.

Figure 4 shows the effect of extracted CPW thickness as a curing liquid and sample thickness on cementitious material heat evolution rate. Cement pore water did not accelerate the hydration reaction such as was seen with lime-saturated water. This may be from the presence of sulfate or other ions in the CPW solution. The effects of CPW and sample thickness on the maximum rate of heat evolution were not as significant as distilled water and lime-saturated water. The ratio of the second and third peak heights did not change significantly with the change in sample thickness because of the more similar ionic concentration between the cure liquid and the pore solution. This shows that changes in sulfate concentration from curing liquid can affect the hydration of cementitious materials.

To quantify the effects of water ponding on the $\mathrm{DOH}$ of cementitious materials, calorimetry was performed on samples with $w / \mathrm{cm}$ of $0.275,0.3,0.325$, and 0.35 at $23^{\circ} \mathrm{C}$ $\left(73^{\circ} \mathrm{F}\right)$ and $\mathrm{w} / \mathrm{cm} 0.275$ and 0.35 at $38^{\circ} \mathrm{C}\left(100^{\circ} \mathrm{F}\right)$. For cement pastes, sample depths of 10,20 , and $30 \mathrm{~mm}(0.39,0.78$, and $1.18 \mathrm{in}$.) were used at $23^{\circ} \mathrm{C}\left(73^{\circ} \mathrm{F}\right)$, whereas sample depths of 10,15 , and $20 \mathrm{~mm}(0.39,0.59$, and 0.78 in.) were used at $38^{\circ} \mathrm{C}\left(100^{\circ} \mathrm{F}\right)$ to determine the effect of curing on the sample thickness. Three $\mathrm{mL}\left(18 \mathrm{in.}^{3}\right)$ of curing water was applied to the top of the paste samples to provide a thin film of approximately $1 \mathrm{~mm}$ (0.039 in.) of curing water. Figure 5 shows the increase in $\mathrm{DOH}$ of cement pastes at 


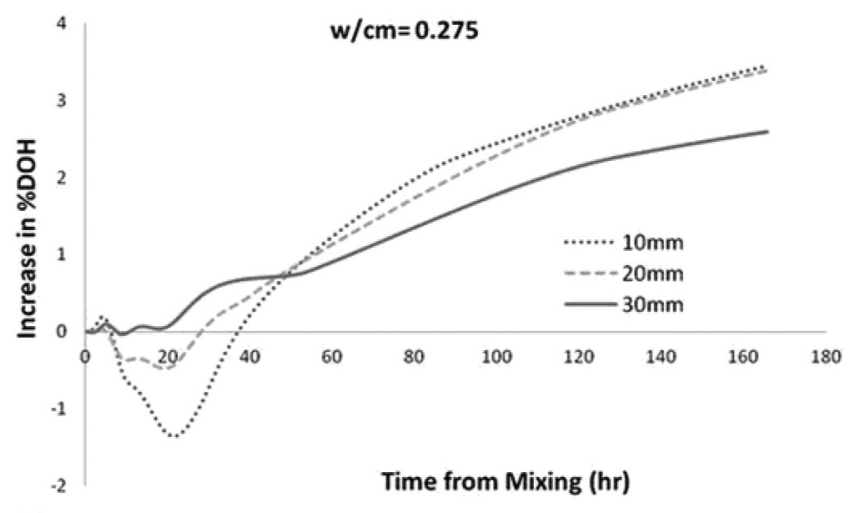

(a)

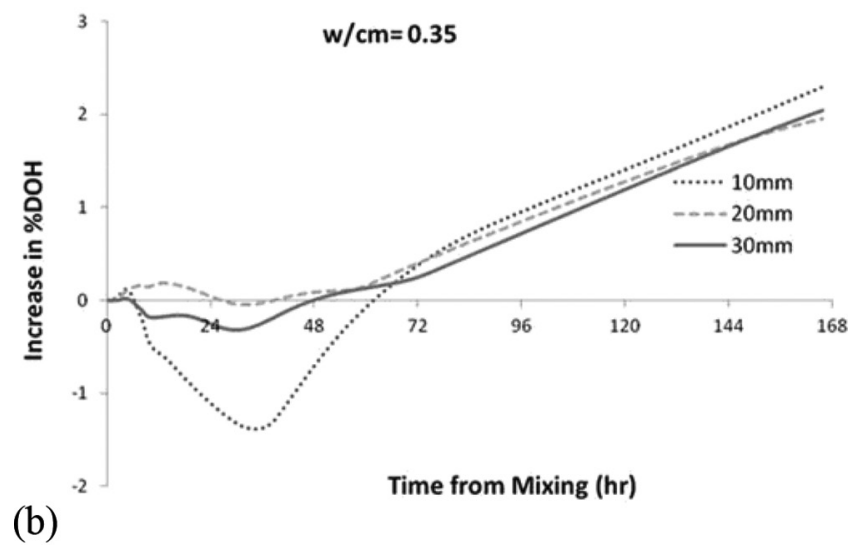

Fig. 5-Increase in percent degree of hydration of watercured sample of Type I cement at $23^{\circ} \mathrm{C}\left(73^{\circ} \mathrm{F}\right):(a) \mathrm{w} / \mathrm{cm}$ $=0.275 ;$ and $(b) \mathrm{w} / \mathrm{cm}=0.35$. (Note: $1 \mathrm{~mm}=0.03937 \mathrm{in}$. $)$

$23^{\circ} \mathrm{C}\left(73^{\circ} \mathrm{F}\right)$ for a 0.275 and $0.35 \mathrm{w} / \mathrm{cm}$. The decrease in the $\mathrm{DOH}$ seen during the first day of hydration with distilled water is likely because of dilution of the calcium ions in solution, making it take slightly longer to reach the calcium supersaturation limit.

Water-cured cement paste samples showed a higher cumulative heat of hydration than sealed cement paste samples after 7 days. The average DOH of different sample thickness for water-cured and sealed samples after 7 days at $23^{\circ} \mathrm{C}\left(73^{\circ} \mathrm{F}\right)$ is presented in Fig. 6. The DOH for the sealed samples increased almost linearly with the increase in $\mathrm{w} / \mathrm{cm}$. Water-cured samples, however, showed a nonlinear response. Figure 7 shows the effect of sample depth and $w / \mathrm{cm}$ on the increase of $\mathrm{DOH}$, compared with the sealed sample of equal thickness after 7 days at the two different temperatures tested. For $w / \mathrm{cm}$ of 0.325 and 0.35 , sample thickness did not have any noticeable effect on the increase in $\mathrm{DOH}$, indicating that the water diffusion during the first week was high enough for the water to penetrate to the bottom of the sample. Water-cured samples at a w/cm of 0.275 showed a lower increase in $\mathrm{DOH}$ than the $0.3 \mathrm{w} / \mathrm{cm}$ sample at all sample thicknesses, possibly because of more limited space for hydrated products to grow.

The use of curing compounds in a sealed condition increased the hydration of cement paste, as shown in Fig. 8. Water-cured samples and the curing compound samples showed very similar increases in DOH, as shown in Fig. 9. The water-based curing compound probably

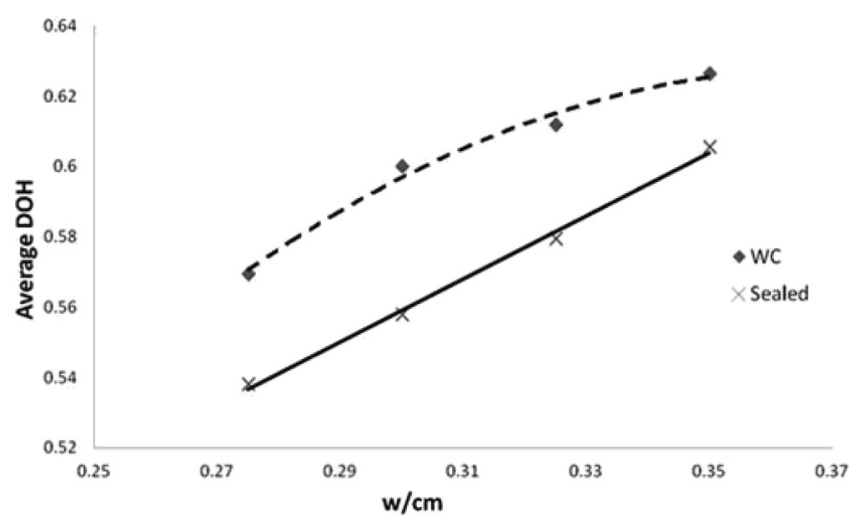

Fig. 6-Effect of w/cm on average DOH of water-cured and sealed samples for $100 \%$ Type I cement paste at $23^{\circ} \mathrm{C}$ $\left(73^{\circ} \mathrm{F}\right)$ after 7 days.

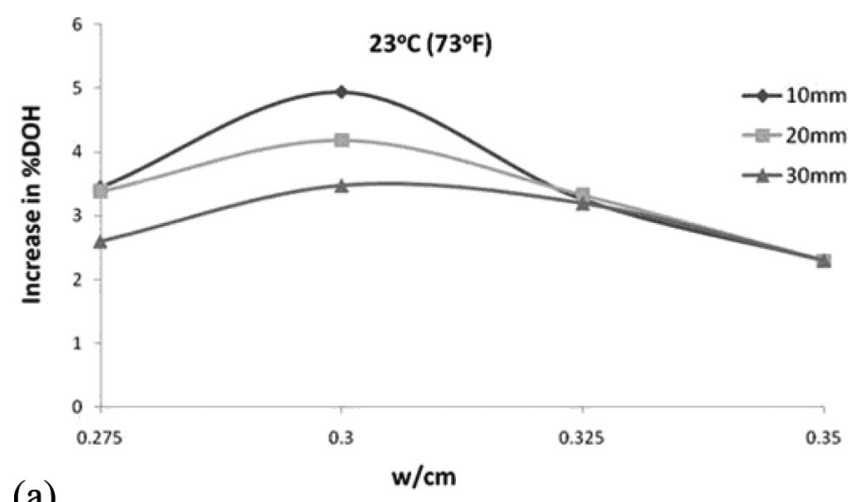

(a)

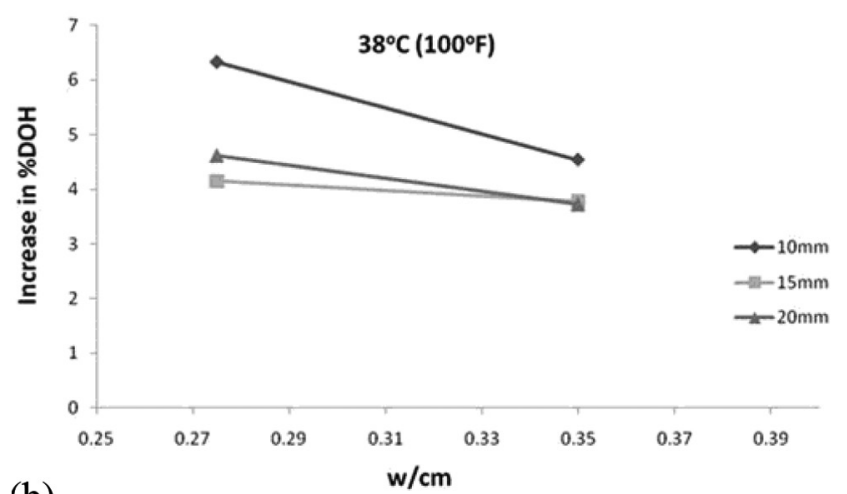

(b)

Fig. 7-Effect of sample depth and $\mathrm{w} / \mathrm{cm}$ on increase in degree of hydration than sealed sample of equal thickness after 7 days for $100 \%$ Type I cement paste: (a) $23^{\circ} \mathrm{C}\left(73^{\circ} \mathrm{F}\right)$; and (b) $38^{\circ} \mathrm{C}\left(100^{\circ} \mathrm{F}\right)$. (Note: $1 \mathrm{~mm}=0.03937 \mathrm{in}$.)

increased the amount of available water for hydration, which increased the cement hydration.

Very little difference was seen in the DOH of mortar samples with internal curing, as would be expected at $w / \mathrm{cm}$ greater than 0.42. Figure 10 shows the effect of presoaked lightweight fine aggregate to improve the hydration of cementitious materials. Even at a $w / \mathrm{cm}$ of 0.45 , the use of FLAIR improved the DOH of mortar much more than external water curing. An increase in the FLAIR provided increased the cement $\mathrm{DOH}$, although with diminishing returns as shown by the percent $\mathrm{DOH}$ increase from the use 


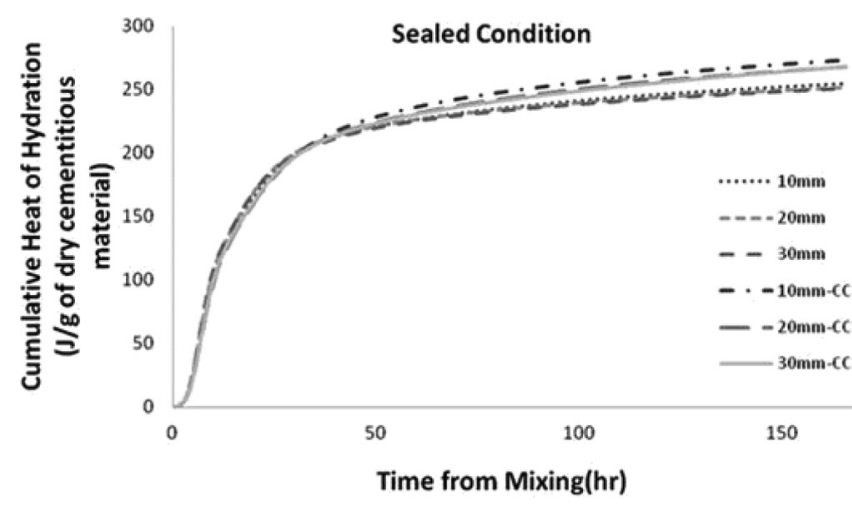

Fig. 8-Effect of curing compound on hydration of cementitious materials for $100 \%$ Type I cement $\mathrm{w} / \mathrm{cm}$ of 0.275 at $23^{\circ} \mathrm{C}\left(73^{\circ} \mathrm{F}\right)$. (Note: $1 \mathrm{~mm}=0.03937 \mathrm{in}$.)

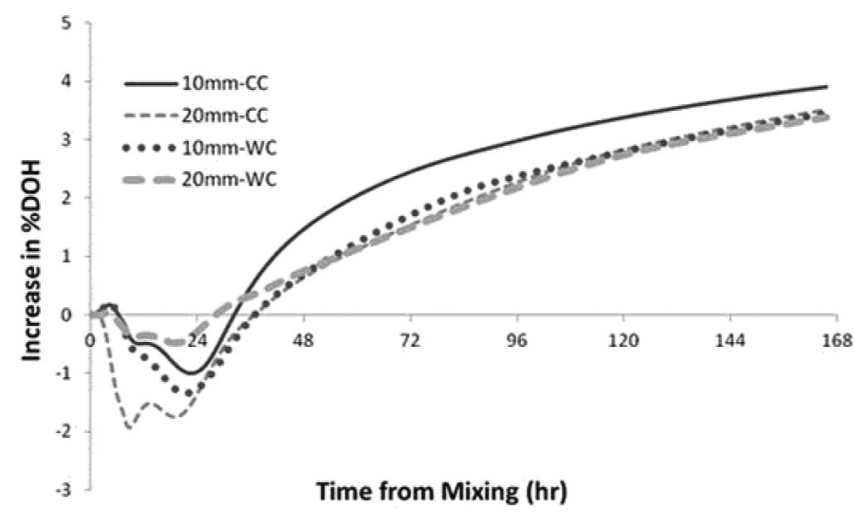

Fig. 9-Comparison between water curing and curing compound at sealed environment for 100\% Type I cement $\mathrm{w} / \mathrm{cm}$ of 0.275 at $23^{\circ} \mathrm{C}\left(73^{\circ} \mathrm{F}\right)$.

of FLAIR. This is because once enough FLAIR was used to fill the space left vacant by chemical shrinkage, adding additional FLAIR would not provide any additional benefit (Henkensiefken et al. 2009).

To understand the effect of curing timing on the strength development of concrete, concrete cylinders were cured using three different curing conditions. Figure 11 shows the concrete strength development for the three curing conditions used. The concrete immersed in water immediately after finishing showed a significant increase in strength compared to sealed curing and delayed wet curing.

\section{DISCUSSION}

For the three types of curing solutions used, the cement pore solution affected the hydration rate the least, with only a small decrease in the peak rates observed. This small decrease is likely because the pore solution in the paste changes with time, with only a small concentration gradient between that above the sample and in the paste. The distilled water affected the peak rates more than that observed with the cement pore solution, with a further decrease in the third peak usually associated with the aluminate and sulfate reaction. The lime-saturated water changed the cement pore solution the most, giving a significant acceleration and decrease in the ratio between the second and third hydration peak heights. For hydration studies on cement paste samples, the curing solution chosen can impact the C-S-H
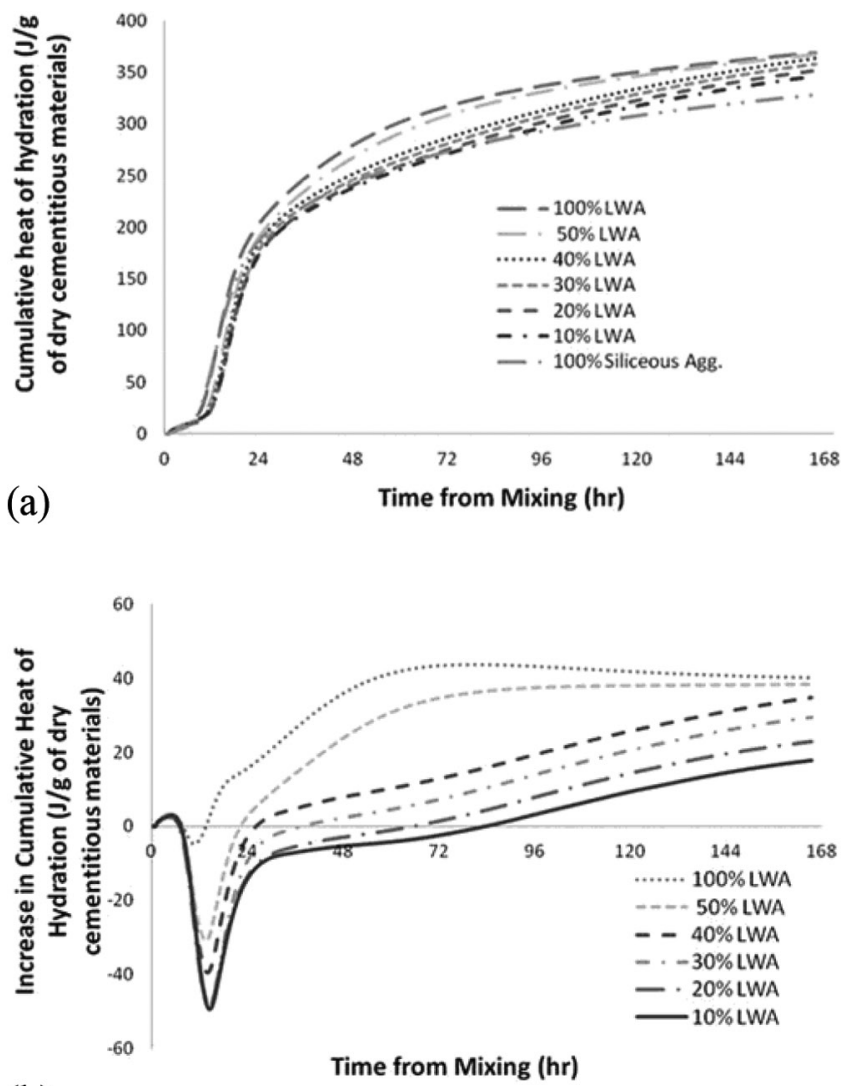

(b)

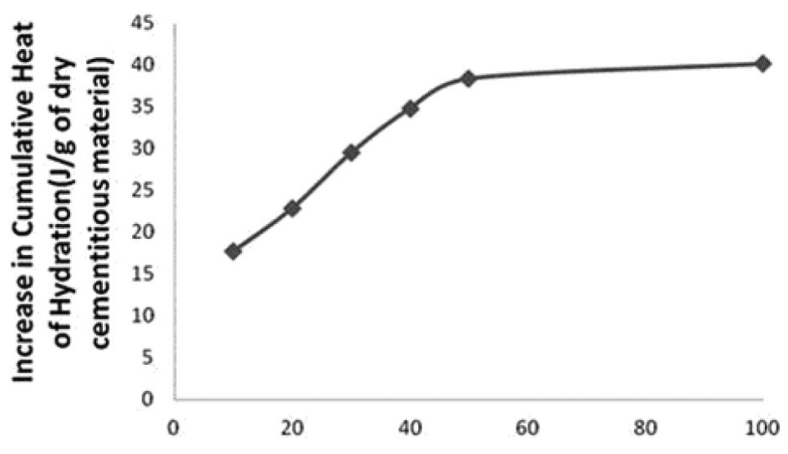

(c)

$\%$ Replacement of sand by FLAIR

Fig. 10-Effect of FLAIR on DOH of mortar $(\mathrm{w} / \mathrm{cm}=$ $0.45)$ at $23^{\circ} \mathrm{C}\left(73^{\circ} \mathrm{F}\right)$ : (a) cumulative heat of hydration; (b) increase in $\% \mathrm{DOH}$ with respect to $100 \%$ siliceous aggregate; and (c) increase in cumulative heat of hydration after 7 days.

nucleation and growth rate by significantly altering when calcium supersaturation is reached and the sulfate dissolution rate and availability.

Both the sealed and water-cured samples generated an equal cumulative heat of hydration up to a certain period of time, after which water availability became a limiting factor. At the time between the sealed and water-cured sample hydration divergence, a significant amount of water still remained in the pores, equivalent to a $w / \mathrm{cm}$ of 0.09 to 0.13 for the samples tested at $23^{\circ} \mathrm{C}\left(73^{\circ} \mathrm{F}\right)$. The large amount of water available at the time of divergence shows that the hydration is probably limited by water movement to the 
unhydrated cement grains and not necessarily by the total amount of water remaining.

The importance of the available water location on curing was especially seen in the samples with FLAIR. The $100 \%$ FLAIR dosage accelerated the DOH increase because of the better dispersion of available water, reducing the limiting effects of water transport. The DOH increase with FLAIR dosages between 50 and $100 \%$ converged to similar values at 7 days because the extra water provided was more than enough to compensate for all of the chemical shrinkage.

The sealed concrete cylinders had $10 \%$ higher strength than the standard moist-room-cured cylinder. The dry state of the cylinders during testing is most likely responsible for the increased strength, even though the sealed specimens should have a lower DOH than the moist-roomcured cylinders. The concrete immersed in water immediately after finishing had $15 \%$ higher strength than the sealed cylinders and $27 \%$ higher strength than the standard moist-room-cured cylinders. This illustrates the difficulty of getting cure water into the concrete after hardening because of the low water diffusivity. One of the concerns about immersing the concrete in water immediately after finishing was that there would be an effective increase in the $w / \mathrm{cm}$ at the top surface; however, this problem was not seen in the tests performed. Although this curing procedure did increase the strength, it is doubtful that it would be representative of in-place concrete strength. Water ponding cannot normally be applied until after setting or penetrate very large distances. These results reinforce the idea that cylinders should be treated according to ASTM C31/C31M (2010) to avoid misleading high compressive strength results. This is because this procedure provides a standard method of judging whether or not the concrete delivered is what was ordered and not because the specified standard curing conditions help the concrete achieve the maximum possible strength.

\section{CONCLUSIONS}

The effects of different curing techniques were studied using isothermal calorimetry and compressive strength experiments. From these experiments, the following conclusions can be drawn:

- Ionic concentration of curing water affects the rate of hydration. Lime-saturated water accelerated hydration probably because of the earlier time when the calcium supersaturation limit was reached. Using a simulated pore solution as the curing medium would appear to have the smallest effect on the hydration. This has application to hydration kinetics studies such as chemical shrinkage experiments that require some form of curing or liquid above the sample.

- FLAIR improved the hydration of cementitious materials more than water curing at the specimen surface. This further emphasizes the importance of water availability during curing. Higher dosages of FLAIR than just that required for chemical shrinkage may not be necessary for complete hydration, but will increase the rate of hydration.

- Curing compounds provided a similar increase in hydration to water curing in a sealed environment when compared to sealed specimens without curing compound or water ponding, probably because of high water content in water-based curing compounds.

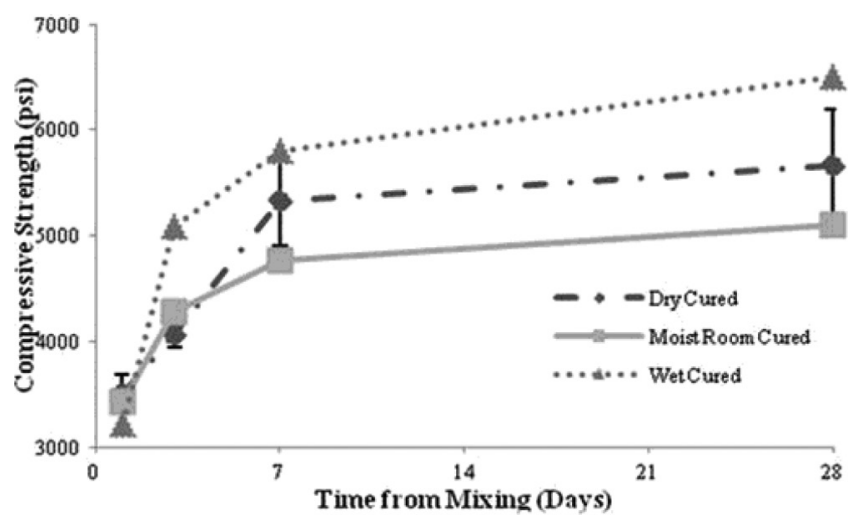

Fig. 11-Concrete cylinder strength development under different curing conditions. (Note: 1 psi $=0.006894 \mathrm{MPa}$.)

- Wet curing immediately after finishing resulted in $27 \%$ higher 28-day cylinder strength than that of cylinders sealed for 24 hours followed by curing in a moist room.

\section{ACKNOWLEDGMENTS}

The support of Kansas State University's Civil Engineering Department and Kansas State University's Transportation Center is acknowledged.

\section{REFERENCES}

ASTM C31/C31M-10, 2010, "Standard Practice for Making and Curing Concrete Test Specimens in the Field," ASTM International, West Conshohocken, PA, 6 pp.

ASTM C33/C33M-11, 2011, "Standard Specification for Concrete Aggregates," ASTM International, West Conshohocken, PA, 11 pp.

ASTM C39/C39M-10, 2010, "Standard Test Method for Compressive Strength of Cylindrical Concrete Specimens," ASTM International, West Conshohocken, PA, 7 pp.

ASTM C150/C150M-02, 2002, "Standard Specification for Portland Cement," ASTM International, West Conshohocken, PA, 8 pp.

ASTM C192/C192M-07, 2007, "Standard Practice for Making and Curing Concrete Test Specimens in the Laboratory," ASTM International, West Conshohocken, PA, 8 pp.

ASTM C305-11, 2011, "Standard Practice for Mechanical Mixing of Hydraulic Cement Pastes and Mortars of Plastic Consistency," ASTM International, West Conshohocken, PA, 3 pp.

ASTM C989/C989M-05, 2005, "Standard Specification for Ground Granulated Blast-Furnace Slag for Use in Concrete and Mortars," ASTM International, West Conshohocken, PA, 5 pp.

ASTM C1240-11, 2011, "Standard Specification for Silica Fume Used in Cementitious Mixtures," ASTM International, West Conshohocken, PA, $7 \mathrm{pp}$.

Bentz, D. P., and Stutzman, P. E., 2006, "Curing, Hydration, and Microstructure of Cement Paste," ACI Materials Journal, V. 103, No. 5, Sept.Oct., pp. 348-356.

Bentz, D. P.; Koenders, E. A. B.; Mönnig, S.; Reinhardt, H. W.; van Breugel, K.; and Ye., G., 2007, "Materials Science-Based Models," Internal Curing of Concrete-State-of-the-Art Report of RILEM Technical Committee 196-ICC, RILEM Publications S.A.R.L., Bagneux, France, pp. 29-43.

Bentz, D. P.; Lura, P.; and Roberto, J. W., 2005, "Mixture Proportioning for Internal Curing," Concrete International, V. 27, No. 2, Feb., pp. 35-40.

Broda, M.; Wirquin, E.; and Duthoit, B., 2002, "Conception of an Isothermal Calorimeter for Concrete-Determination of the Apparent Activation Energy," Materials and Structures, V. 35, No. 251, pp. 389-394.

Copeland, L. E.; Kantro, D. L.; and Verbeck, G., 1960, "Chemistry of Hydration of Portland Cement," 4th International Symposium of the Chemistry of Cement, Washington, DC, pp. 429-465.

D'Aloia, L., and Chanvillard, G., 2002, "Determining the 'Apparent' Activation Energy of Concrete: $E_{a}$-Numerical Simulations of the Heat of Hydration of Cement," Cement and Concrete Research, V. 32, No. 8, pp. 1277-1289.

De Schutter, G., and Taerwe, L., 1996, "Degree of Hydration-Based Description of Mechanical Properties of Early-Age Concrete," Materials and Structures, V. 29, No. 7, pp. 335-344.

Grasley, Z., 2006, "Measuring and Modeling the Time-Dependent Response of Cementitious Materials to Internal Stresses," PhD dissertation, 
Department of Civil and Environmental Engineering, University of Illinois at Urbana-Champaign, Urbana, IL, $238 \mathrm{pp.}$

Henkensiefken, R.; Bentz, D. P.; Nantung, T.; and Weiss, J., 2009 "Volume Change and Cracking in Internally Cured Mixtures Made with Saturated Lightweight Aggregate under Sealed and Unsealed Conditions," Cement and Concrete Composites, V. 31, No. 7, pp. 427-437.

Hoff, G., and Elimov, R., 1995, "Concrete Production for the Hibernia Platform," Supplementary Paper in Second CANMET/ACI International Symposium on Advances in Concrete Technology, Las Vegas, NV, pp. 717-739.

Jaouadi, I., 2008, "Etude numérique et expérimentale du retrait endogène de la pâte de ciment au jeune âge," doctoral thesis, Laboratory of Materials of Construction, Swiss Federal Institute of Technology at Lausanne, Lausanne, Switzerland, $191 \mathrm{pp}$.

Jensen, O. M., and Hansen, P. F., 1996, "Autogenous Deformation and Change of the Relative Humidity in Silica Fume-Modified Cement Paste," ACI Materials Journal, V. 93, No. 6, Nov.-Dec., pp. 539-543.

Jensen, O. M., and Hansen, P. F., 2001, "Water-Entrained Cement-Based Materials: Principles and Theoretical Background," Cement and Concrete Research, V. 31, No. 4, pp. 647-654.

Jensen, O. M., and Hansen, P. F., 2002, "Water-Entrained CementBased Materials: II-Experimental Observations," Cement and Concrete Research, V. 32, No. 6, pp. 973-978.

Jensen, O. M.; Hansen, P. F.; Lachowski, E. E.; and Glasser, F. P., 1999,

"Clinker Mineral Hydration at Reduced Relative Humidities," Cement and Concrete Research, V. 29, No. 9, pp. 1505-1512.

Kada-Benameur, H.; Wirquin, E.; and Duthoit, B., 2000, "Determination of Apparent Activation Energy of Concrete by Isothermal Calorimetry," Cement and Concrete Research, V. 30, No. 2, pp. 301-305.

Klieger, P., 1957, "Early High-Strength Concrete for Prestressing," Proceeding in World Conference on Prestressed Concrete, San Francisco, CA, pp. A5(1)-A5(14).

Kovler, K., and Jensen, M., 2005, "Novel Technique for Concrete Curing," Concrete International, V. 27, No. 9, Sept., pp. 39-42.
Kovler, K.; Bentur, A.; Lange, D. A.; Bentz, D. P.; Van Breugel, K.; Lura, P.; Zhutovsky, S.; and Souslikov, A., 2004, "Autogenous Curing of High-Strength Cementitious Materials by Fine Uniformly Distributed Lightweight Aggregate," Research Report to U.S.-Israel Binational Science Foundation, Technion, Haifa, 78 pp.

Lura, P.; Winnefeld, F.; and Klemm, S., 2010, "Simultaneous Measurements of Heat of Hydration and Chemical Shrinkage on Hardening Cement Pastes," Journal of Thermal Analysis and Calorimetry, V. 101, No. 3, pp. 925-932.

Mather, B., 2001, "Self-Curing Concrete, Why Not?" Concrete International, V. 23, No. 1, Jan., pp. 46-47.

Powers, T. C., 1947, "A Discussion of Cement Hydration in Relation to the Curing of Concrete," Bulletin 25, Research Laboratories of the Portland Cement Association, Chicago, IL, pp. 178-188.

Powers, T. C., and Brownyard, T. L., 1948, "Studies of the Physical Properties of Hardened Portland Cement Paste," Bulletin 22, Research Laboratories of the Portland Cement Association, Chicago, IL, 892 pp.

Price, W. H., 1951, "Factors Influencing Concrete Strength," ACI Journal, V. 47, No. 2, Feb., pp. 417-432.

Schindler, A. K., and Folliard, K. J., 2005, "Heat of Hydration Models for Cementitious Materials," ACI Materials Journal, V. 102, No. 1, Jan.Feb., pp. 24-33.

Van Breugel, K., 1998, "Prediction of Temperature Development in Hardening Concrete," R. Springenschmid, ed., Prevention of Thermal Cracking in Concrete at Early Ages, E\&FN Spon, London, UK, pp. 51-75. Villarreal, V. H., 2005, "Building Better Pavements through Internal Hydration-A Work in Progress," Proceedings of the R. Villarreal International Symposium on Durability of Concrete, Monterrey, México, 13 pp.

Wadsö, L., 2010, "Operational Issues in Isothermal Calorimetry," Cement and Concrete Research, V. 40, No. 7, pp. 1129-1137.

Weber, S., and Reinhardt, H. W., 1997, "A New Generation of HighPerformance Concrete: Concrete with Autogenous Curing," Advanced Cement Based Materials, V. 6, No. 2, pp. 59-98 